\title{
術後神経認知障害 一脳内炎症を標的とした予防・治療戦略一
}

河野崇

\begin{abstract}
要約：高齢手術患者の増加に伴い, 術後神経認知障害への対策が重要課題となっている。術 後神経認知障害として, 術後せん妄と術後認知機能障害が挙げられる。術後せん妄と術後認 知機能障害はそれぞれ異なる疾患単位と考えられているが，共通する病態として脳内炎症が 注目されている。脳内炎症は, 活性化したミクログリアから過剩に炎症性サイトカインが産生・ 放出された状態である。特に，海馬ミクログリアは加齢により炎症性反応性が増加すること が知られており, 高齢者に術後神経認知障害が生じやすい原因と考えられる。また, 全身麻酔, 手術侵襲に伴う全身炎症，痛み，急性ストレス反応，神経障害などは脳内炎症を誘発する。 したがって，これらの要因を最小化することが術後神経認知障害の予防・治療に重要である。 本稿では術後神経認知障害の病態に関する最新の研究動向を示すとともに, 脳内炎症を標的 とした予防・治療戦略を考察したい。
\end{abstract}

Key words: (1) geriatric surgery, (2) postoperative delirium, (3)postoperative cognitive dysfunction, (4) neuroinflammation, (5) microglia

\section{I . はじめに}

高齢手術患者において, 頻度が高く長期予後に重大 な影響を与える合併症として術後神経認知障害があ る1)。代表的な術後神経認知障害には, 術後せん妄 (postoperative delirium, POD) と術後認知機能障害 (postoperative cognitive dysfunction, POCD) がある。 術後神経認知障害の発症は, 退院後の日常生活の質 (QOL) および活動性 (activities of daily living, ADL) 低下の独立危険因子となる 2),3)。術後神経認知障害の 臨床像および病態を知り, その予防・治療戦略を策定 することは, 今後の高齢者周術期医療のあり方に関わ る重要課題である。一方, 術後神経認知障害の詳細な 病態機序はこれまで明らかでなかった。しかし, 近年, 脳内炎症 (neuroinflammation) の重要性が臨床・基礎 研究で示されている ${ }^{4)}$ 。本稿では術後神経認知障害の 病態に関する最新の研究動向を示すとともに, 脳内炎 症を標的とした術後神経認知障害の予防・治療戦略を 考察したい。

\section{II. 術後神経認知障害の臨床}

POD，POCD，および認知症はそれぞれ異なる疾患 単位と考えられている。しかし, これらの病態は互い に密接に関連している。例えば, 維断的研究において, PODを発症した患者は, その後, 認知症を発症するリ スクが 8 倍程度増加する5)。一方, 認知症はPOD発症 の最も重要な危険因子である ${ }^{3) 。 ~}$

1) PODの臨床像

PODは手術を契機とする意識, 認知機能, 知覚, お よび注意障害で, 通常術後早期から数日間の間に急性 に発症する急性脳機能障害である ${ }^{6)}$ 。高齢者の術後合 併症のなかで最も頻度が高く，術後患者の10～ $50 \%$ で生じる。過活動型のせん妄は, 不穏, 暴言, 暴行が 出現するため, その後の治療経過に悪影響を及ぼし, 患者家族や医療従事者の負担を増加させる。一方, 傾 眠や抑うつ状態が主体の低活動型のせん妄では, その 見逃しが問題となる。予後は過活動型よりも低活動型 で不良であるとの報告がある7)。PODは，それ自体は 可逆的であるが, ADL/QOLを含む患者の長期予後に 


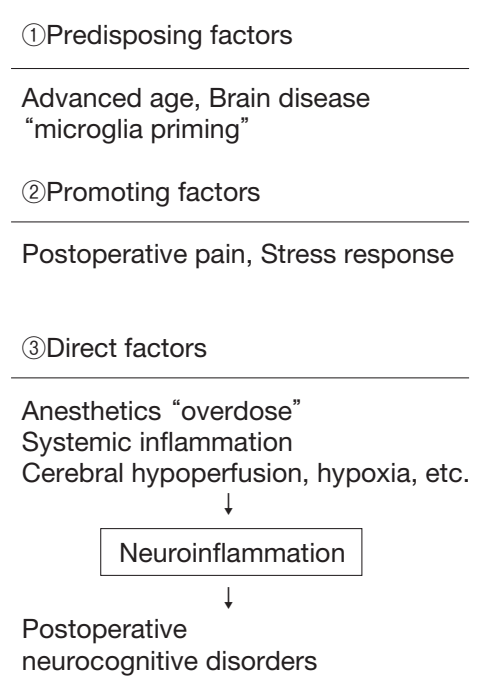

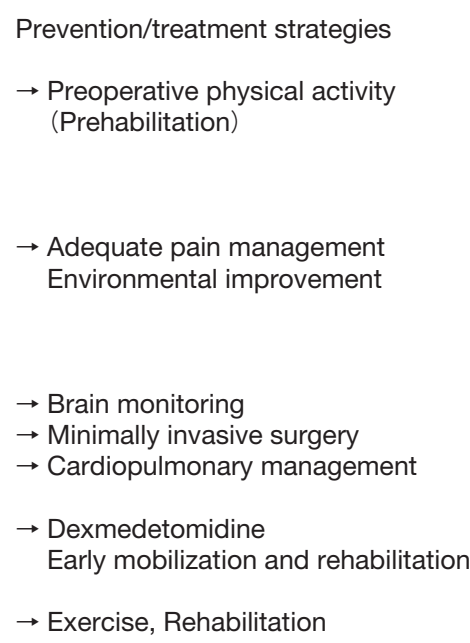

Fig. 1 Pathophysiological processes in postoperative neurocognitive disorders and prevention/treatment strategies

Onset processes of postoperative neurocognitive disorder based on a neuroinflammatory hypothesis (left column) and prevention/treatment strategy for each process (right column) are shown.

関連する重要な疾患である。

\section{2) POCDの臨床像}

POCDは, 軽度から中等度の認知機能障害が術後数 週間から数力月持続する状態である。“手術する前は 普通だったのに, 手術してから急に認知症になって…” という話はよく耳にする。実際に, POCDの存在は 1950年代から報告されていた。POCDが注目される ようになったのは, 1998年に報告された高齢非心臟 手術を対象とした大規模前向き試験によるところが大 き(8)。本研究では, 6 種類の認知機能検査を組み合 わせて, それらを術前, 術後 1 週間および術後 3 カ月に 行っている。その結果, POCD は, 術後 1 週間で $25.8 \%$, 術後3カ月では $9.9 \%$ に発生していた。さらに, 術後 1 週間のPOCD は, その後の就労困難, 術後 3 力 月の POCD は長期死亡率上昇と関連することも報告 された2)。

一方, POCDに関していくつかの研究計画上の問題 点もある9)。POD とは異なり，POCDには明確な評価 基準が存在せず，これまでに 100 通り以上の評価基準 が用いられている。また, 認知機能は正常な老化の過 程でも例外なく低下する。ただし, 認知機能の経時的 軌道曲線は遺伝, 環境要因にも規定されるため個人差 が大きい。つまり, 手術前後の認知機能の比較だけで は真のPOCD は判定できず, 患者個々の認知機能の経 時的軌道曲線が手術・麻酔を契機にどれほど下方移動 したかを評価しなければ，前後即因果の誤謬を否定で
きない。その他の交絡因子も考虑すると, $\mathrm{POCD}$ を正 確に証明することは今後も困難と言わざるをえない。

\section{III. 術後神経認知障害の病態機序}

術後神経認知障害は, 準備因子である加齢や中枢神 経系疾患により脆弱化した脳に, 誘発・直接因子とな る周術期ストレスが加わることにより発症する(Fig. 1)。術後神経認知障害が発症する際の脳内の病態につ いては，これまで様々な検討がなされてきた。その中 で, 術後神経認知障害の予防・治療の標的となりうる ものとして, 近年特に注目されているのが脳内炎症で ある。

\section{1) 脳内炎症仮説}

脳内炎症は, 脳内で炎症性サイトカインが生理的な 範囲・期間を超えて過剩に放出された状態である4)。 種々の周術期のストレスが多様な経路を介して最終的 に脳内炎症に至り, 術後神経認知障害が発症するとさ れるのが脳内炎症仮説である10)。これまでに, アル ツハイマー型認知症を含む神経変性疾患, 慢性疲労症 候群，うつ病などの発症過程にも脳内炎症が関与する とされている。

神経細胞を支えるグリア細胞であるミクログリアは 感染, 組織損傷, 神経変性などに応答して炎症性サイ トカインを産生・放出することから脳内炎症に中心的 な役割を果たすと考えられている4),11),12)。正常なミ 
クログリアの機能は, 脳の恒常性維持に必須であるが, 過剩に活性化したミクログリアは, 大量の炎症性サイ トカインを放出し, 脳内炎症を引き起こす。ミクログ リアは, アルッハイマー型認知症の病態に重要なアミ ロイド $\beta(\mathrm{A} \beta)$ や夕ウ蛋白の蓄積によっても活性化さ れる。記憶中枢である海馬は脳内でもミクログリアが 最も多い脳部位の一つであり, 脳内炎症の影響を強く 受ける。

炎症性サイトカインは, 記憶過程に重要な海馬の長 期増強 (long-term potentiation, LTP) を抑制する13)。 この反応は急性に生じることから PODの病態に関連 していると考えられる。ヒト剖検脳を用いた検討でも， せん妄を発症した脳は,せん妄がなかった年齢調整正 常者の脳と比較して, 有意にミクログリアの活性化を 示唆する病理所見が多くみられる。培養神経細胞を用 いた実験では, 炎症性サイトカインの曝露は濃度・時 間依存性に神経細胞のアポトーシスを誘導する。さら に, 炎症性サイトカインは, 酸化ストレスの主な原因 物質である活性酸素種 (reactive oxygen species, ROS) や活性窒素種 (reactive nitrogen species, RNS) を増加させ, 神経細胞死および神経変性を促進す る14),15)。これらの反応は, より長期の POCDや認知 症の病態に関連している可能性がある。実際に，せん 妄後に認知症を発症した患者の剖検脳ではアルッハイ マー病理 (A $\beta$, 夕ウ蛋白の凝集・蓄積) が少なく, 脳 内炎症が認知症の主な病態機序であると考えられ る5)。したがって, 過剩な急性脳内炎症 (PODなど) は, より早期に解除することが, その後の遷延・重症化を 予防するために重要であると考えられる。

\section{2) Microglia priming}

ミクログリアは, 正常な加齢過程に伴い “microglia priming” と呼ばれる形態的および機能的変化が生じ る (Fig. 2)。Primed microgliaでは, 突起が短縮し肥 大化するという形態変化に加え, 炎症反応に関連する MHC II (major histocompatibility complex II), CD 11, CD 86, CD 68, Toll様受容体などの膜蛋白の発現 が増加する。Primed microgliaは, 活性化準備状態の ミクログリアと考えられ，軽微な炎症刺激であっても

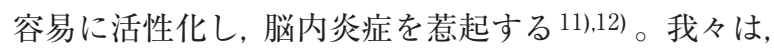
急性単離した海馬ミクログリアにおいて,リポ多糖 (lipopolysaccharide, LPS)により誘導される炎症性サ イトカインの放出反応は, 若年と比較して高齢で劇的 に増加することを報告した (Fig. 2) 16)。また, primed microgliaから活性型に変化したミクログリアは, 正常 な状態である静止型に戻りにくい。これらの特徴は, 高齢脳がストレスに脆弱であり, 急性脳内炎症 (POD
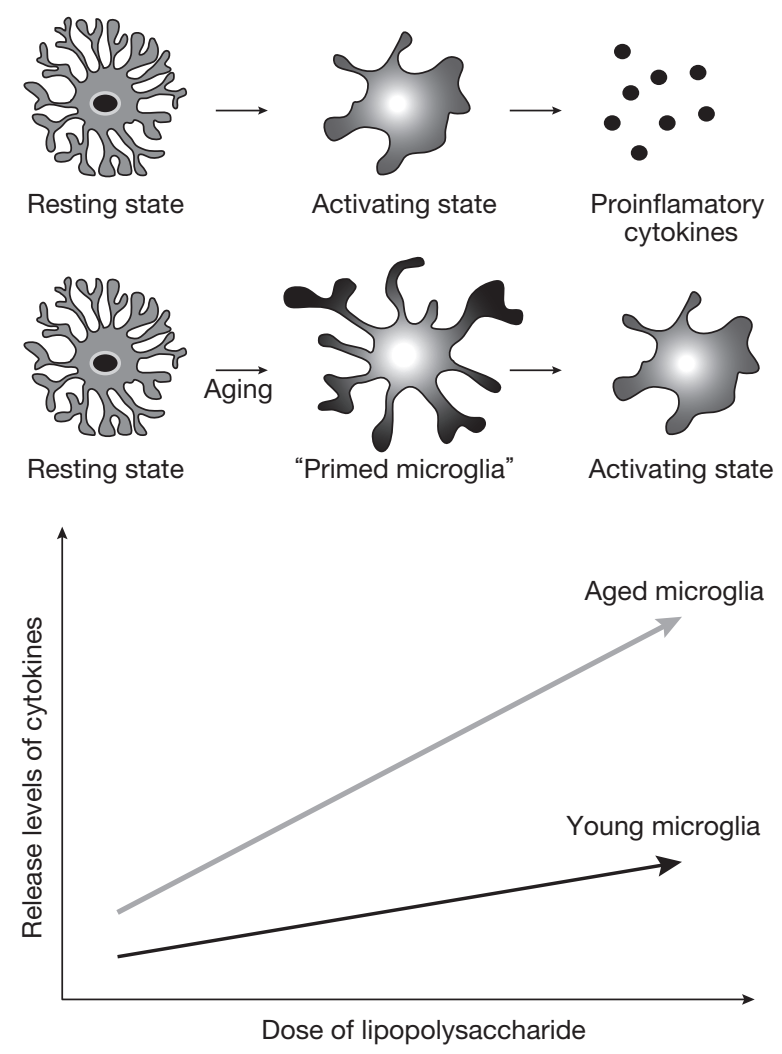

Fig. 2 Age-related phenotypic change in microglia Microglia normally remain in a quiescent state, i.e., resting microglia, with a ramified morphology. When triggered by appropriate stimulation, microglia rapidly transformed from a resting state to an activated state with a de-ramified shape. With normal aging, microglia from elderly brains show a shift towards a more activated morphology, exhibiting de-ramified condensed processes and enlarged cell bodies. Elderly microglia isolated from the hippocampus, compared with those from young brains, are shifted towards an inflammatory phenotype, a process known as "microglia priming". Primed microglia show a greater production of pro-inflammatory cytokines in response to immune stimulation with a peripheral inflammatory challenge.

など) が生じやすく，また脳内炎症が遷延 $(\mathrm{POCD}$ ど）しやすいことに関連すると考えられる。一方， microglia priming は加齢に加え, 脳梗塞・出血などの 脳疾患後に増悪する。脳疾患の合併・既往が, 術後神 経認知障害の危険因子であることに関与していると考 えられる10)。

\section{IV．術後神経認知障害と脳内炎症}

術後神経認知障害の誘発・直接因子となりうる周術 期ストレスとして, 麻酔, 手術侵襲に伴う全身炎症, 痛み, 急性ストレス反応, 神経障害などが挙げられる。 
これらの周術期ストレスは, 液性あるいは神経性経路 を介して脳内炎症を誘発すると考えられている。

\section{1) 麻酔}

高齢動物を用いたin vivo臨床前研究においては, 1.0MAC (minimum alveolar concentration) 相当 · 数 時間のイソフルラン麻酔により脳内炎症とそれに関連 する記憶障害が生じることが示されている17),18)。若 年動物あるいは短時間の麻酔では, これらの反応は生 じないことから, 麻酔薬による脳内炎症は, 年齢と麻 酔時間に依存すると考えられる16),19)。一方, in vitro 実験系の結果はinvivo実験系とは一致していない。 培養グリア細胞を用いたin vitro研究では, ほとんど の麻酔薬は濃度依存性にグリア細胞からの炎症性サイ トカインの放出に対して抑制的に作用する20),21)。し たがって, in vivo研究による麻酔薬の脳内炎症誘発作 用はミクログリアに対する直接作用というょり, むし ろ神経系を介する作用であると考えられる。

臨床研究においても, 高用量の麻酔薬曝露が術後神 経認知障害と関連することを示唆する報告がある。深 麻酔では脳波においてバースト・サプレッション（脳 波活動のバーストと平坦脳波が交互に繰り返される非 特異的脳波パターンで重篤な脳障害時に出現する)が 生じる22),23)。以前は, 深麻酔によるバースト・サプ レッションは脳代謝抑制の指標で脳保護作用が期待さ

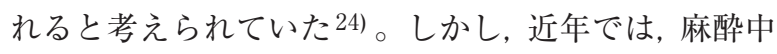
のバースト・サプレッション時間が長いほど術後神経 認知障害の発生頻度が増加する可能性が報告されてい る25)。吸入麻酔薬および静脈麻酔薬ともに, 多くの 麻酔薬は神経細胞のミトコンドリア機能を抑制す る26)。麻酔薬によるミトコンドリア機能抑制作用は, 濃度依存性であるが臨床使用濃度内でも生じうる。 PODモデルマウスを用いた研究では, 大脳皮質におけ るATP (adenosine triphosphate) 濃度低下の程度とせ ん妄様行動が関連することが示されている27)。ミト コンドリア機能は加齢とともに低下すると考えられて いることから, 高齢者ではその影響がより大きいと推 測される28)。バースト・サプレッションは, 麻酔薬 の過量投与を示唆しており, 高齢脳ではミトコンドリ ア機能障害から後述する神経障害を介する脳内炎症を 引き起こす可能性がある。

\section{2) 全身炎症}

手術侵襲に伴う全身炎症は, 中枢一未梢連関を介し た生体応答により脳内炎症を誘発しうる29)。高齢動 物に対して外科手術やLPSの全身投与を行うと脳内 炎症が生じることが一貫して報告されている 16),30),31)。 全身炎症により生じた末梢性サイトカインが血液脳関
門を破壊・突破して中枢神経系に影響を与える，ある いは活性化した組織マクロファージが中枢神経系に侵 入して脳内炎症を惹起させる病態が推測されている。 しかし, 未梢性サイトカイン濃度と脳内炎症の程度は 必ずしも相関しないことから, このような液性経路だ けでは中枢一未梢関連は説明できない16)。我々は高 齢ラットにParabiosis（並体結合：2 匹の動物を結合し て血管をつなげ循環共有する）を用いて術後脳内炎症 の液性因子の影響を検討した ${ }^{32)}$ 。Parabiosisの一方の みに開腹手術を行うと, 非手術ラットにも手術ラット と同程度の末梢血サイトカインが増加するが, 脳内炎 症は非手術ラットでは生じず手術ラットのみで生じ た。このことは, 術後脳内炎症は末梢性サイトカイン の直接作用よりも手術侵襲の神経性経路を介した中枢 神経刺激がより重要である可能性を示唆している。

\section{3) 痛み}

痛みが術後神経認知障害に関連することが多く報告 されている33)。痛みによるストレス反応が中枢神経 系に影響すると考えられる。また, 痛みは入院中の認 知症患者の行動 - 心理症状のなかの攻撃性に強く関連 することが報告されている34)。我々は, 高齢ラット 開腹手術モデルを用いて, 術後急性痛がPOCD発症の 誘因となることを明らかとした ${ }^{35)}$ 。また, 術後急性 痛に関連するPOCDは, 鎮痛方法 (オピオイド, 消炎 鎮痛薬, 区域麻酔)に関係なく適切な鎮痛を行うこと

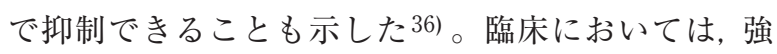
い術後痛に加えて, 不十分なオピオイド投与量がPOD の発生率増加に関連するとの報告がある37)。一方で, オピオイドはせん妄の誘発因子でもある。入院中のが ん患者では, モルヒネ換算で $90 \mathrm{mg} / \mathrm{day}$ 以上のオピオ イド鎮痛薬の使用でせん妄の発症リスクが $40 \%$ 増加 する38)。また, 合成オピオイド鎮痛薬のメペリジン は代謝物ノルメペリジンに神経毒性および抗コリン作 用を有することから, PODを誘発する危険性がある ため高齢者での使用は控えるべきである ${ }^{33) 。 ~}$

\section{4）急性ストレス反応}

入院環境, 不安, 手術侵襲などの精神的・身体的入 トレスは視床下部－下垂体－副腎系を賦活する。その 結果, 副腎から放出される副腎皮質ステロイドが, 術 後神経認知障害の発症に関連する可能性がある ${ }^{39) 。 ~}$

糖質コルチコイドは, 薬剤性せん妄の原因薬物とし て知られている40)。ステロイド薬によるせん妄は, 高用量 (60 m g/day 以上) の使用や急激な増量 - 中止 により発症しやすい。ステロイドは, 未梢組織におい ては強力な抗炎症作用を有するが, 中枢神経系では逆 の作用を有する可能性がある。ステロイドにより, ミ 
クログリアの炎症反応性 (免疫刺激に対する炎症性サ イトカインの放出応答) が立進することが基礎研究で 示されているからである41),42)。したがって，内因性 ステロイドの増加あるいは外因性ステロイドの高用量 投与は, かえって術後脳内炎症を増悪する可能性があ る。最近の多施設無作為化二重盲検実薬対照試験では, 術中のデキサメタゾンの予防的投与は, 心臓手術後の POCD出現率に影響しなかったことが報告されてい 万 ${ }^{43)}$ 。

\section{5) 神経障害}

低酸素血症や脳低灌流などの代謝障害は, 神経機能 を直接的に障害し神経認知障害を引き起こす。高龄者 では, 動脈硬化を基盤とする脳血管疾患を合併するこ とも少なくなく, 特に危険性が高い。また, 局所で神 経障害が生じた場合, 生理的恒常性維持反応としてミ クログリアが活性化され，結果的に脳内炎症を惹起す る。神経障害を評価するバイオマーカとして $\mathrm{S} 100 \beta$

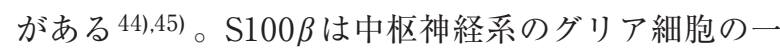
つであるアストロサイトの活性化の指標でもあり, 神 経障害時に脳春髄液から循環血液中に移行する。した がって, 血漿中の $\mathrm{S} 100 \beta$ 濃度は神経障害ならびに脳内 炎症反応の程度を反映すると考えられている。実際に, $\mathrm{S} 100 \beta$ の増加とせん妄の発症が関連するとの報告もあ る46),47)。

\section{V. 術後神経認知障害の予防・治療戦略}

術後神経認知障害の中でも POCDについて, 臨床的 な予防・治療法はほとんど検討されていない。POD に関しては, ガイドラインが策定され, 最新の情報が まとめられている48)。しかし, それらの予防・治療 法には科学的根拠が妄しいのが現状である。いったん 重度の術後神経認知障害が発症するとその治療法は限 定的である。したがって, 術後神経認知障害は予防が 重要であるが, 術後神経認知障害に対する周術期の複 雑な誘発・直接因子を完全に避けることは不可能とい える。

PODに対する薬物治療の中心は抗精神病薬であ る 49,50)。しかし, 抗精神病薬はPOD の出現頻度を低 下できるかもしれないが，退院後の患者長期予後には 効果がない，あるいは調べられていない。つまり，抗 精神病薬はPODの表面的な症状をマスクするだけで, 本質的な病態を改善していないかもしれない。抗精神 病薬の副作用も無視できず, 現時点でその使用は積極 的に推奨できない。ただし，実臨床においては，他に 打つ手がなく抗精神病薬を使用せざるを得ない状況に
しばしば遭遇する。脳内炎症は, 過剩になると病的な 意義があるが, それ自体は脳機能の恒常性維持に必須 である。したがって, 脳内炎症を薬理学的に抑制する ような薬物療法は現実的ではない。術後神経認知障害 への最善の予防・治療戦略とは, (1)患者の自己予備力 を引き出すこと, (2)調節可能なリスク因子を可能な限 り取り除く介入を行うこと，と考えられる (Fig. 1)。

次に, 術後神経認知障害の病態機序に基づき有効と 考えられる介入方法について, その可能性も含めて以 下にまとめる。

\section{1）術前運動・認知介入}

術後神経認知障害は, 手術・麻醉を契機に発症する ため術前からの介入が有効と考えられる。特に, 運動 が脳内炎症を抑制できる可能性が多く報告されてい る 51,52$) 。$ 実際に, アルッハイマー病などの加齢性認 知障害では, 身体活動介入の有効性が広く受け入れら れている。我々は, 高齢ラットPOCD モデルを用いて, 開腹手術前 2 週間の術前身体活動介入が海馬ミクログ リアの炎症反応性を若年ラットと同梯なレベルまで引 き下げ, 術後の脳内炎症およびそれに関連する POCD を予防できることを報告した ${ }^{16)}$ 。術前身体活動介入 は, 手術決定から手術までの待機期間を利用できるこ と, 手術による身体制限がないこと, 呼吸器など他の 合併症予防にも有効である可能性があること, 非薬物 治療で適応性が広いこと, などの利点がある。運動習 慣は退院後の健康寿命維持にも大きく関わる。周術期 管理チームには, 高齢患者に術前身体活動介入を推奖 するだけでなく, 手術を契機に退院後も運動を積極的 に生活に取り入れるような指導も求められる。

適切な運動が, 認知機能を含む多様で全身性の健康 増進効果を生むことは自明である。一方, 運動が身体 へ及ぼす機序については十分に解明されていない。骨 格筋は, 生体最大臟器 (体重の約 $40 \%$ ) であり, 身体活 動に応答した可塑性に富む臟器である。近年, 骨格筋 の収縮刺激により骨格筋自体から生理活性物質が分泌 され, 内分泌的に遠隔臟器一作用するという報告が多 くなされている53),54)。骨格筋由来生理活性因子は, 総称してマイオカインと呼ばれており,これまでに複 数のマイオカインが報告されている。運動介入による 抗脳内炎症効果もマイオカインの関与が推測されてい る。今後, 骨格筋およびマイオカインを標的とした周 術期治療戦略が注目されると考えられる。

\section{2) 脳モニタリングを用いた麻酔濃度の調節}

前述した通り，ほとんどの全身麻酔薬は高濃度・長 時間曝露下で神経毒性が生じる危険性があると考えら れる。したがって, 全身麻酔薬の過剩投与は術後神経 
認知障害の医原性リスク因子といえる 55),56)。高齢者 では, 全身麻酔に必要な投与量は若年者と比較して減 少する。薬物動態や薬力学の加齢変化を理解するとと もに, 脳モニタリングを指標として患者個々の状態に 応じた必要最小限の投与量で維持すべきである。特に, 過剩投与を示唆するバースト・サプレッションを生じ させないようにするのが重要である。バースト・サプ レッションはBIS (bispectral index) を決定する要素 の一つでもある。BIS<20ではバースト・サプレッ ションが直線的に増加するとされる。オピオイド鎮痛 薬や区域麻酔を併用し, 全身麻酔薬の使用量を節減す ることも重要と考えられる。一方, 認知症患者や脳疾 患合併患者では麻酔濃度を極限まで下げているにもか かわらず, BISが低下し適切な值を維持できない症例 も経験する。このような, いわば“anesthetic frail”は 術後神経認知障害の危険因子と推測される。つまり, 全身麻酔は高齢脳に対するストレステストであり, 術 後神経認知障害発症の予測因子にもなりうると考えら れる。

3）脳内炎症の抑制 一デクスメデトミジンの可能 性一

近年, $\alpha_{2}$ アドレナリン作動性鎮静薬であるデクスメ デトミジンがPODの予防に有用とする報告があ る57)。我々は, 高齢ラットPOCDモデルを用いて, 鎮 静用量のデクスメデトミジンの術中使用が, 術後の脳 内炎症およびそれに関連するPOCDを予防できるこ とを報告した21)。In vivo実験系で, 正常なミクログ リア機能を維持し, かつ抗脳内炎症効果を発揮する麻 酔・鎮静薬は, これまでにデクスメデトミジンのみで ある。ミクログリアには $\alpha_{2}$ アドレナリン受容体が発 現していることから, デクスメデトミジンがこの受容 体を介して脳内炎症を抑制したと考えられる。今後さ らなる検討が期待される。

4) 術後鎮痛・早期離床・リハビリテーション

優れた術後鎮痛が有用であることに議論の余地はな い。一方, 鎮痛法の違いが術後神経認知障害の発症リ スクに影響を与えるかどうかは明らかではない。高齢 認知症患者では痛みの評価が極めて困難で, 痛みが過 小評価され, 鎮痛薬の不十分な投与から行動・ 心理症 状 (特に興奮・攻撃性)の増悪を招いている懸念があ る34)。今後の早急な対策が必要な課題の一つである。 現時点では, 多面的鎮痛法で忍容性を保ちつつ患者の 満足度を向上させることが求められる。また, 積極的 な早期離床・リハビリテーションは, 術前身体活動介 入と同様な理由で, 術後神経認知障害の予防・治療に おける合理的かつ確立した方策と考えられる。

\section{VI. おわりに}

高齢者が手術を受ける機会は今後も確実に増加す る。術後神経認知障害は, 高齢者が抱える多くの老年 医学的な問題と関連している。周術期管理チームは, 認知機能障害をはじめ, サルコペニア, フレイル, 低 栄養, 多臓器疾患, 多剂服用など高齢者特有の全身状 態を的確に把握し対応しなければならない。その実現 のためには, 多職種連携・協働が必須であり, このよ うな医療こそ高齢者医療の最大の特徴および課題とい える。術後神経認知障害への対策をはじめとして, 高 齢者に対してエビデンスに基づいた最適な周術期医療 の構築に向けた努力を継続する必要がある。

本論文は, 第44回日本集中治療医学会学術集会 (2017 年, 札棍) 企画セミナーおよびシンポジウムでの講演内容に加筆 したものである。

本稿の著者には, 規定されたCOIはない。

\section{文 献}

1) Deiner S, Silverstein JH. Postoperative delirium and cognitive dysfunction. Br J Anaesth 2009;103 Suppl:i41-6.

2) Steinmetz J, Christensen KB, Lund T, et al; ISPOCD Group. Long-term consequences of postoperative cognitive dysfunction. Anesthesiology 2009;110:548-55.

3) Bilotta F, Lauretta MP, Borozdina A, et al. Postoperative delirium: risk factors, diagnosis and perioperative care. Minerva Anesthesiol 2013;79:1066-76.

4) Hovens IB, Schoemaker RG, van der Zee EA, et al. Postoperative cognitive dysfunction: Involvement of neuroinflammation and neuronal functioning. Brain Behav Immun 2014;38:202-10.

5) Davis DH, Muniz Terrera G, Keage H, et al. Delirium is a strong risk factor for dementia in the oldest-old: a population-based cohort study. Brain 2012;135:2809-16.

6) Martins S, Fernandes L. Delirium in elderly people: a review. Front Neurol 2012;3:101.

7) Hosker C, Ward D. Hypoactive delirium. BMJ 2017;357:j2047.

8) Moller JT, Cluitmans P, Rasmussen LS, et al. Long-term postoperative cognitive dysfunction in the elderly ISPOCD1 study. ISPOCD investigators. International Study of Post-Operative Cognitive Dysfunction. Lancet 1998;351:857-61.

9) Avidan MS, Evers AS. The Fallacy of Persistent Postoperative Cognitive Decline. Anesthesiology 2016;124: 255-8.

10) Steinman L. Modulation of postoperative cognitive decline via blockade of inflammatory cytokines outside the brain. Proc Natl Acad Sci U S A 2010;107:20595-6.

11) Perry VH, Holmes C. Microglial priming in neurodegenerative disease. Nat Rev Neurol 2014;10:217-24.

12) Niraula A, Sheridan JF, Godbout JP. Microglia Priming with Aging and Stress. Neuropsychopharmacology 
2017;42:318-33.

13) Yirmiya R, Goshen I. Immune modulation of learning, memory, neural plasticity and neurogenesis. Brain Behav Immun 2011;25:181-213.

14) Fischer R, Maier O. Interrelation of oxidative stress and inflammation in neurodegenerative disease: role of TNF. Oxid Med Cell Longev 2015;2015:610813.

15) Lull ME, Block ML. Microglial activation and chronic neurodegeneration. Neurotherapeutics 2010;7:354-65.

16) Kawano T, Eguchi S, Iwata H, et al. Impact of preoperative environmental enrichment on prevention of development of cognitive impairment following abdominal surgery in a rat model. Anesthesiology 2015;123:160-70.

17) Wu X, Lu Y, Dong Y, et al. The inhalation anesthetic isoflurane increases levels of proinflammatory TNF- $\alpha$, IL-6, and IL-1 $\beta$. Neurobiol Aging 2012;33:1364-78.

18) Culley DJ, Baxter M, Yukhananov R, et al. The memory effects of general anesthesia persist for weeks in young and aged rats. Anesth Analg 2003;96:1004-9.

19) Callaway JK, Jones NC, Royse AG, et al. Memory impairment in rats after desflurane anesthesia is age and dose dependent. J Alzheimers Dis 2015;44:995-1005.

20) Tanaka T, Kai S, Matsuyama T, et al. General anesthetics inhibit LPS-induced IL-1 $\beta$ expression in glial cells. PLoS One 2013;8:e82930.

21) Yamanaka D, Kawano T, Nishigaki A, et al. Preventive effects of dexmedetomidine on the development of cognitive dysfunction following systemic inflammation in aged rats. J Anesth 2017;31:25-35.

22) Brown EN, Lydic R, Schiff ND. General anesthesia, sleep, and coma. N Engl J Med 2010;363:2638-50.

23) Ferron JF, Kroeger D, Chever O, et al. Cortical inhibition during burst suppression induced with isoflurane anesthesia. J Neurosci 2009;29:9850-60.

24) Zaidan JR, Klochany A, Martin WM, et al. Effect of thiopental on neurologic outcome following coronary artery bypass grafting. Anesthesiology 1991;74:406-11.

25) Fritz BA, Kalarickal PL, Maybrier HR, et al. Intraoperative Electroencephalogram Suppression Predicts Postoperative Delirium. Anesth Analg 2016;122:234-42.

26) La Monaca E, Fodale V. Effects of anesthetics on mitochondrial signaling and function. Curr Drug Saf 2012;7:126-39.

27) Peng M, Zhang C, Dong Y, et al. Battery of behavioral tests in mice to study postoperative delirium. Sci Rep 2016;6:29874.

28) Payne BA, Chinnery PF. Mitochondrial dysfunction in aging: Much progress but many unresolved questions. Biochim Biophys Acta 2015;1847:1347-53.

29) Rabin BS, Cohen S, Ganguli R, et al. Bidirectional interaction between the central nervous system and the immune system. Crit Rev Immunol 1989;9:279-312.

30) Kawano T, Morikawa A, Imori S, et al. Preventive effects of multisensory rehabilitation on development of cognitive dysfunction following systemic inflammation in aged rats. J Anesth 2014;28:780-4.

31) Catorce MN, Gevorkian G. LPS-induced murine neuroinflammation model: main features and suitability for pre-clinical assessment of nutraceuticals. Curr Neuropharmacol 2016;14:155-64

32) Kawano T, Eguchi S, Iwata H, et al. Pregabalin can prevent, but not treat, cognitive dysfunction following abdominal surgery in aged rats. Life Sci 2016;148:211-9.

33) Fong HK, Sands LP, Leung JM. The role of postoperative analgesia in delirium and cognitive decline in elderly patients: a systematic review. Anesth Analg 2006;102: 1255-66.

34) Sampson EL, White N, Lord K, et al. Pain, agitation, and behavioural problems in people with dementia admitted to general hospital wards: a longitudinal cohort study. Pain 2015;156:675-83.

35) Chi H, Kawano T, Tamura T, et al. Postoperative pain impairs subsequent performance on a spatial memory task via effects on $\mathrm{N}$-methyl-D-aspartate receptor in aged rats. Life Sci 2013;93:986-93.

36) Kawano T, Takahashi T, Iwata H, et al. Effects of ketoprofen for prevention of postoperative cognitive dysfunction in aged rats. J Anesth 2014;28:932-6.

37) Morrison RS, Magaziner J, Gilbert M, et al. Relationship between pain and opioid analgesics on the development of delirium following hip fracture. J Gerontol A Biol Sci Med Sci 2003;58:76-81.

38) Gaudreau JD, Gagnon P, Roy MA, et al. Opioid medications and longitudinal risk of delirium in hospitalized cancer patients. Cancer 2007;109:2365-73.

39) Calcia MA, Bonsall DR, Bloomfield PS, et al. Stress and neuroinflammation: a systematic review of the effects of stress on microglia and the implications for mental illness. Psychopharmacology (Berl) 2016;233:1637-50.

40) Sirois F. Steroid psychosis: a review. Gen Hosp Psychiatry 2003;25:27-33.

41) Frank MG, Thompson BM, Watkins LR, et al. Glucocorticoids mediate stress-induced priming of microglial pro-inflammatory responses. Brain Behav Immun 2012;26:337-45.

42) Nair A, Bonneau RH. Stress-induced elevation of glucocorticoids increases microglia proliferation through NMDA receptor activation. J Neuroimmunol 2006;171: 72-85.

43) Ottens TH, Dieleman JM, Sauër AM; DExamethasone for Cardiac Surgery (DECS) Study Group. Effects of dexamethasone on cognitive decline after cardiac surgery: a randomized clinical trial. Anesthesiology 2014;121:492-500.

44) Sen J, Belli A. S100B in neuropathologic states: the CRP of the brain?. J Neurosci Res 2007;85:1373-80.

45) Donato R, Sorci G, Riuzzi F, et al. S100B's double life: intracellular regulator and extracellular signal. Biochim Biophys Acta 2009;1793:1008-22.

46) Khan BA, Farber MO, Campbell N, et al. S100 calcium binding protein $\mathrm{B}$ as a biomarker of delirium duration in the intensive care unit - an exploratory analysis. Int J Gen Med 2013;6:855-61.

47) Al Tmimi L, Van de Velde M, Meyns B, et al. Serum protein S100 as marker of postoperative delirium after off-pump coronary artery bypass surgery: secondary analysis of two prospective randomized controlled trials. Clin Chem Lab Med 2016;54:1671-80.

48) American Geriatrics Society Expert Panel on Postoperative Delirium in Older Adults. American Geriatrics Society abstracted clinical practice guideline for postoperative delirium in older adults. J Am Geriatr Soc 2015;63:142-50.

49) Girard TD, Pandharipande PP, Carson SS, et al; MIND Trial Investigators. Feasibility, efficacy, and safety of antipsychotics for intensive care unit delirium: the MIND randomized, placebo-controlled trial. Crit Care Med 2010;38:428-37.

50) Hakim SM, Othman AI, Naoum DO. Early treatment with 
risperidone for subsyndromal delirium after on-pump cardiac surgery in the elderly: a randomized trial. Anesthesiology 2012;116:987-97.

51) Svensson M, Lexell J, Deierborg T. Effects of Physical Exercise on Neuroinflammation, Neuroplasticity, Neurodegeneration, and Behavior: What We Can Learn From Animal Models in Clinical Settings. Neurorehabil Neural Repair 2015;29:577-89.

52) Spielman LJ, Little JP, Klegeris A. Physical activity and exercise attenuate neuroinflammation in neurological diseases. Brain Res Bull 2016;125:19-29.

53) Schnyder S, Handschin C. Skeletal muscle as an endocrine organ: PGC-1 $a$, myokines and exercise. Bone 2015;80:115-25.

54) Pedersen BK. Edward F. Adolph distinguished lecture: muscle as an endocrine organ: IL-6 and other myokines. J Appl Physiol (1985) 2009;107:1006-14.

55) Chan MT, Cheng BC, Lee TM, et al; CODA Trial Group. BIS-guided anesthesia decreases postoperative delirium and cognitive decline. J Neurosurg Anesthesiol 2013;25: 33-42.

56) Radtke FM, Franck M, Lendner J, et al. Monitoring depth of anaesthesia in a randomized trial decreases the rate of postoperative delirium but not postoperative cognitive dysfunction. Br J Anaesth 2013;110:198-105.

57) Su X, Meng ZT, Wu XH, et al. Dexmedetomidine for prevention of delirium in elderly patients after non-cardiac surgery: a randomised, double-blind, placebocontrolled trial. Lancet 2016;388:1893-902.

\title{
Abstract \\ Neuroinflammation as a preventive and therapeutic target for postoperative neurocogni- tive disorders
}

\author{
Takashi Kawano
}

Department of Anesthesiology and Intensive Care Medicine, Kochi Medical School

Kohasu, Oko-cho, Nankoku, Kochi 783-8505, Japan

With the rapidly aging population in Japan, the number of geriatric patients undergoing surgical procedures under anesthesia is expected to increase. Furthermore, postoperative neurocognitive disorders, such as postoperative delirium (POD) and cognitive dysfunction (POCD), are now well-recognized as the most frequent complications of surgery, especially in geriatric patients. More importantly, epidemiological studies consistently show that POD/POCD are not transient phenomena, but are associated with long-term disability and increased mortality rates. Although POD and POCD are considered distinct clinical entities, recent preclinical and clinical findings suggest that neuroinflammation is a common underlying mechanism involved in the development of these disorders. Neuroinflammation is characterized by microglia activation and under increased brain levels of pro-inflammatory cytokines, such as TNF- $\alpha$ and IL-1 $\beta$. Particularly, microglia in a normal aged brain is reportedly shifted towards an inflammatory phenotype, known as "microglia priming". The microglia priming in the hippocampus may make elderly surgical patients highly susceptible to the development of neuroinflammation and related cognitive disorders following a peripheral immune challenge. Furthermore, during the perioperative period, many factors including general anesthetics/sedatives, surgery-related systemic inflammation, an acute stress response, and nerve injury can contribute to the development of neuroinflammation via both neuronal and humoral pathways. Therefore, to prevent and manage postoperative neurocognitive disorders, it is crucially important to minimize these intrinsic or iatrogenic risk factors. This review provides a pathophysiological overview of postoperative neurocognitive disorders and current perspectives on prevention, treatment, and intervention strategies.

Key words: (1) geriatric surgery, (2) postoperative delirium, (3) postoperative cognitive dysfunction, (4) neuroinflammation, (5) microglia 